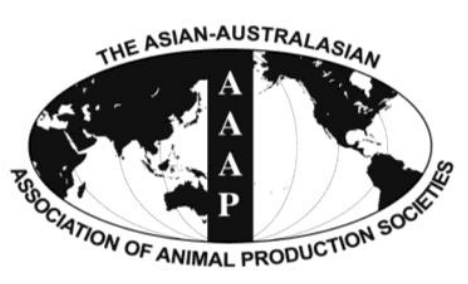

Open Access

Asian Australas. J. Anim. Sci.

Vol. 27, No. 8 : 1189-1195 August 2014

http://dx.doi.org/10.5713/ajas.2014.14017

www.ajas.info

pISSN 1011-2367 elSSN 1976-5517

\title{
Polymorphism, Expression of Natural Resistance-associated Macrophage Protein 1 Encoding Gene (NRAMP1) and Its Association with Immune Traits in Pigs
}

\author{
Xiaoling Ding ${ }^{\mathrm{a}}$, Xiaodong Zhang ${ }^{\mathrm{a}}$, Yong Yang ${ }^{1}$, Yueyun Ding, Weiwei Xue, Yun Meng, \\ Weihua Zhu, and Zongjun Yin* \\ College of Animal Science and Technology, Anhui Agricultural University, 230036 Hefei, China
}

\begin{abstract}
Natural resistance-associated macrophage protein 1 encoding gene (NRAMP1) plays an important role in immune response against intracellular pathogens. To evaluate the effects of NRAMP1 gene on immune capacity in pigs, tissue expression of NRAMP1 mRNA was observed by real time quantitative polymerase chain reaction (PCR), and the results revealed NRAMP1 expressed widely in nine tissues. One single nucleotide polymorphism (SNP) (ENSSSCG00000025058: g.130 C>T) in exon1 and one SNP (ENSSSCG00000025058: g.657 A>G) in intron1 region of porcine NRAMP1 gene were demonstrated by DNA sequencing and PCRRFLP analysis. A further analysis of SNP genotypes associated with immune traits including contain of white blood cell (WBC), granulocyte, lymphocyte, monocyte (MO), rate of cytotoxin in monocyte (MC) and CD4/CD8 T lymphocyte subpopulations in blood was carried out in four pig populations including Large White and three Chinese indigenous breeds (Wannan Black, Huai pig and Wei pig). The results showed that the SNP (ENSSSCG00000025058: g.130 C > T) was significantly associated with level of WBC \% $(\mathrm{p}=$ $0.031), \mathrm{MO} \%(\mathrm{p}=0.024), \mathrm{MC} \%(\mathrm{p}=0.013)$ and $\mathrm{CD} 4^{-} \mathrm{CD}^{+} \mathrm{T}$ lymphocyte $(\mathrm{p}=0.023)$. The other SNP (ENSSSCG00000025058: g.657 $\mathrm{A}>\mathrm{G})$ was significantly associated with the level of MO\% $(\mathrm{p}=0.012), \mathrm{MC} \%(\mathrm{p}=0.019)$ and $\mathrm{CD}^{-} \mathrm{CD}^{+} \mathrm{T}$ lymphocyte $(\mathrm{p}=0.037)$. These results indicate that the NRAMP1 gene can be regarded as a molecular marker for genetic selection of disease susceptibility in pig breeding. (Key Words: Pig, Natural Resistance-associated Macrophage Protein 1 (NRAMP1), Polymorphism, Expression, Association)
\end{abstract}

\section{INTRODUCTION}

The natural resistance-associated macrophage protein 1 encoding gene (NRAMP1) belongs to a large gene family encoding divalent cation transporters that are localized to late endosomes/lysosomes (Blackwell et al., 2000). The NRAMP1 protein is targeted to the membrane of the microbe-containing phagosome, where it may modify the intraphagosomal milieu to affect microbial replication (Canonne-Hergaux et al., 1999). The NRAMPl gene also called solute carrier family 11 member 1 (SLC11A1) gene and is the first positional cloned gene related to infectious

\footnotetext{
* Corresponding Author: Yin Zongjun. Tel: +86-551-65786303, Fax: +86-551-65786303, E-mail: yinzongjun@ahau.edu.cn

${ }^{1}$ Anhui Antai Pig Breeding Co., LTD., Hefei 340100, China.

${ }^{a}$ These authors contributed equally to this work.

Submitted Jan. 8, 2014; Revised Mar. 21, 2014; Accepted Apr. 14, 2014
}

disease susceptibility in mouse (Vidal et al., 1993). In mammals, NRAMPl gene is associated with the transport of iron and other divalent cations, and the transition metal irons are essential for maintain divalent metal homeostasis, including regulation of transcription through DNA binding proteins and metal response elements (Blackwell, 2003; Courville et al., 2006).

The NRAMP1 protein has 12 conserved transmembrane domains, two N-linked glycosylation sites, and a transport motif. These conserved domains perform various important functions. Mutations of these conserved domains are associated with various diseases in human. Polymorphisms of the human Nramp1 gene are significantly associated with pulmonary Mycobacterium avium complex infection (Tanaka et al., 2007), Crohn's disease (Gazouli et al., 2008), rheumatoid arthritis (Ates et al., 2009), type 1 diabetes (T1D) (Yang et al., 2011). In pig, the cDNA of NRAMPI 
gene has been reported and several single nucleotide polymorphism (SNPs) were also detected and some were found to be associated with the fecal bacteria counts of piglets after challenging with Salmonella cholevasuis (Tuggle et al., 1997; 2005).

Considering the important role of NRAMP1 gene in defending bacterial and viral infection, in this study, we investigated its mRNA expression in different tissues, identified the polymorphisms of porcine NRAMPl gene, and then analyzed their association with some immune traits to evaluate its potential effects in four pig populations including Large White and three Chinese native breeds (Wannan Black, Huai pig, and Wei pig).

\section{MATERIALS AND METHODS}

\section{Animals}

The animals used in this study were 466 pigs, including Large White (140) and three Chinese indigenous breeds, Wannan Black pig (118), Huai pig (105), Wei pig (103). All pigs were raised in 2012 and 2013 under standard indoor conditions at the experimental farm of Academy of Agricultural Sciences of Anhui province, China. After the vaccination with classical swine fever live vaccine, blood samples were collected (day 35). All blood samples were directly injected into VACUETTE Serum Clot Activator tubes. Ear tissue samples of all pigs were also collected for DNA extraction. Eight different tissues, including heart, liver, spleen, lung, kidney, lymph node, brain and thymus, were collected from three 35-day-old Huai pigs. For each tissue, three samples were collected, then immediately frozen in liquid nitrogen and stored at $-80^{\circ} \mathrm{C}$ for spatial expression analysis.

\section{Total RNA extraction and genomic DNA isolation}

The total RNA was extracted from different tissues with a TRIzol reagent (Invitrogen, USA). In order to prevent serious contamination with genomic DNA, DNase I treatment of the total RNA was carried out before firststrand cDNA synthesis. The RNA quality was checked by $0.8 \%$ agarose gel electrophoresis, stained with $0.5 \mu \mathrm{g} / \mathrm{mL}$ ethidium bromide, showing the $28 \mathrm{~S}$ and $18 \mathrm{~S}$ rRNAs clearly. Then reverse transcription was performed for the firststrand cDNA synthesis. All supplies and reagents were RNase-free. First, we incubated the total RNA at $70^{\circ} \mathrm{C}$ for 5 min to destabilize the secondary structure of RNA, and then immediately put it on the ice for at least $2 \mathrm{~min}$; second, thoroughly mix various reagents (moloney murine leukemia virus [M-MLV] Buffer, dNTP, M-MLV reverse transcriptase, Oligo(dT) and RNAsin) (Promega, Madison, WI, USA) with the total RNA on the ice; finally, the mixture was placed in the thermal cycler to accomplish the first-strand
cDNA synthesis followed by the program: $42^{\circ} \mathrm{C} 1 \mathrm{~h}, 95^{\circ} \mathrm{C}$ 10 min. Genomic DNA was isolated from the ear tissue samples of Large White, Wannan Black, Huai pig and Wei pig using phenol/chloroform extraction and ethanol precipitation (Sambrook et al., 1989).

\section{Measurement of immune traits in blood}

Immune traits were contain of white blood cell (WBC), granulocyte, lymphocyte, monocyte (MO), rate of cytotoxin in monocyte (MC) and CD4/CD8 $\mathrm{T}$ lymphocyte subpopulations, All blood samples were directly injected into VACUETTE Serum Clot Activator tubes for detection of blood parameters and T lymphocyte subpopulations; All these hematological parameters were measured by MEK6318K type full automatic Hematology Analyzer (Nihon Kohden, Tokyo, Japan). Rate of cytotoxin in monocytes was detected by rapid colorimetric assay of a multiwall scanning spectrophotometer (Mosmann, 1983). The percentages of various $\mathrm{CD} 4 / \mathrm{CD} 8 \mathrm{~T}$ lymphocyte subpopulations were obtained by the double cytofluorometric analysis. The blood cells were incubated with $10 \mu \mathrm{L}$ of mouse anti porcine CD4-FITC (Serotec, Oxford, UK) and $10 \mu \mathrm{L}$ of mouse anti porcine CD8-RPE (Serotec, UK) for $30 \mathrm{~min}$, and then washed with $0.1 \mathrm{M}$ phosphate buffer solution ( $\mathrm{pH} 7.2)$, containing $0.3 \%$ bovine serum albumin). The stained cells were detected by EPICS Flow Cytometer (BeckmanCoulter Company, Brea, CA, USA).

\section{mRNA expression by real time quantitative polymerase chain reaction}

Based on the NRAMP1 gene mRNA sequence (ENSEMBLE Transcript ID: ENSSSCT00000024413), the reverse transcriptase-polymerase chain reaction (PCR) amplification method was used to detect mRNA expression of the NRAMP1 gene. The first strand cDNA was synthesized in the presence of $2 \mu \mathrm{g}$ total RNA, $0.5 \mu \mathrm{M}$ oligo(dT) 18, $200 \mu \mathrm{M}$ dNTPs, $10 \mathrm{U}$ RNAsin (Promega, Madison, WI, USA), $1 \times$ M-MLV RT buffer, and $300 \mathrm{U}$ MMLV reverse transcriptase (Promega, USA) in a volume of $50 \mu \mathrm{L}$ at $40^{\circ} \mathrm{C}$ for $1 \mathrm{~h}$. A specific primer setting for NRAMP1 gene mRNA expression analysis was designed to eliminate potential confounding results from genomic DNA contamination (Table 1). Another specific primer set (GAPDH-F1 5'-TGAGACACGATGGTGAAGGT-3' and GAPDH-R1 5'-GGCATTGCTGATGATCTTGA-3') was designed to amplify the porcine house-keeping gene glyceraldehyde3-phosphate dehydrogenase (GAPDH) mRNA (GenBank accession number: AF017079) as a positive control. The PCR experiments were performed with an ABI Prism 7900 HT sequence-detection system (Applied Biosystems, Foster, CA, USA), using SYBR Green PCR Master Mix according to the manufacturer's 
Table 1 Primers used for mRNA expression and SNPs detection of the porcine NRAMP1 gene

\begin{tabular}{|c|c|c|c|c|}
\hline Fragments & Primers sequence $\left(5^{\prime}-3^{\prime}\right)$ & Product size $(b p)$ & PCR (Tm) & Used for \\
\hline NRAMP1-1 & $\begin{array}{l}\text { CGGGCTTGGAAGGTCTTTTC } \\
\text { CTCCTGATGCTCTCCTCCTG }\end{array}$ & 560 & 59.0 & SNP identification \\
\hline NRAMP1-2 & $\begin{array}{l}\text { AGGCTCTGCTTCTCACACAT } \\
\text { TTCGGGATGGGGATCTTCTC }\end{array}$ & 260 & 59.0 & SNP detection \\
\hline NRAMP1-3 & $\begin{array}{l}\text { TGCATGCTCCACTCACCC } \\
\text { GAGCCATGTATGCCACCTTG }\end{array}$ & 430 & 59.5 & SNP identification \\
\hline NRAMP1-41 & $\begin{array}{l}\text { GGAGACCGCCAGTTTGCC } \\
\text { AGGCTAGGGGTCAAATTGGA }\end{array}$ & 620 & 60.0 & SNP identification \\
\hline NRAMP1-42 & $\begin{array}{l}\text { CTCTGGTGTAGGCTGGCG } \\
\text { CCAGGCTAGAGGTCGAATCA }\end{array}$ & 420 & 59.5 & SNP identification \\
\hline NRAMP1-Q & $\begin{array}{l}\text { ACTTCTTAGGGGCCTGTTCC } \\
\text { GGGCGATGGTGGATTCAATC }\end{array}$ & 210 & 56.5 & mRNA expression \\
\hline
\end{tabular}

SNP, single nucleotide polymorphism; NRAMP1, natural resistance-associated macrophage protein 1; PCR, polymerase chain reaction.

protocol. In each assay, $1 \mu \mathrm{L}$ of cDNA was added to $19 \mu \mathrm{L}$ of mix containing $10 \mu \mathrm{L} 2 \times$ SYBR green SuperReal PreMix (Tiangen, Beijing, China), $0.4 \mu \mathrm{L}$ of each primer and $8.2 \mu \mathrm{L}$ RNase free $\mathrm{H}_{2} \mathrm{O}$. The reaction was amplified at $95^{\circ} \mathrm{C}$ for 15 min, followed by 40 cycles of $95^{\circ} \mathrm{C} 10 \mathrm{~s}$ and $56.5^{\circ} \mathrm{C} 30 \mathrm{~s}$. For each miRNA, three replicates were performed, and all of the reactions were run in triplicate. The cycle threshold was collected from each reaction, and the relative expression level of NRAMPI gene mRNA to GAPDH mRNA was evaluated using the $2^{-\Delta \Delta C T}$ method (Hellemans et al., 2007).

\section{SNP identification and genotyping of the porcine NRAMP1 gene}

The porcine NRAMP1 genes consist of four exons and three introns (ENSEMBLE gene ID: ENSSSCG00000025058), and using porcine genomic DNA, we designs five primer pairs for the NRAMPl gene including all exon regions (Table 1). All PCR fragments were purified with a Gel Extraction Mini Kit (Beijing Tiangen Biotechnology, Beijing, China) and then sequenced directly. Polymorphisms of NRAMPl gene were identified through sequence comparison of the obtained same PCR fragments from two Large White, two Wannan Black and two Huai pigs using DNAMAN (version 5.2.10, Lyn-non Biosoft, Quebec, Canada). In order to detect the SNPs, direct sequencing of the PCR fragments and PCR-RFLP methods were used. For the PCR-RFLP method, at first, the PCR products $(12 \mu \mathrm{L})$ were digested with $10 \mathrm{U}$ of restriction enzyme, mixed with $2 \mu \mathrm{L}$ of $10 \times \mathrm{T}$ buffer and 2 $\mu \mathrm{L} 0.01 \%$ bovine serum albumin, and added water up to 20 $\mu \mathrm{L}$. The mixtures were incubated at $37^{\circ} \mathrm{C}$ overnight, then the digested PCR products were analyzed by $3 \%$ to $4 \%$ agarose gel electrophoresis and ethidium bromide staining. The gel was visualized by Gel Doc XR system (Bio-Rad, Hercules, CA, USA). The genotypes were identified according to the restriction fragment patterns with Sma I restriction enzyme and later confirmed by sequencing in ABI 377 DNA sequencer (Applied Biosystems, USA).

\section{Association analysis}

Statistical analysis between the polymorphisms of the NRAMP1 gene and the immune traits were performed using PROC MIXED of SAS9.13 (SAS Institute, Cary, NC, USA). The model was as below following:

$$
\mathrm{Y}_{i j k l m n o}=\mu+\mathrm{S}_{i}+\mathrm{Sex}_{j}+\mathrm{B}_{k}+\mathrm{G}_{l}+\mathrm{p}_{k m}+\mathrm{q}_{k m n}+e_{i j k l m n o}
$$

where $\mathrm{Y}_{i j k l m n o}$ is the observation on the 35 th day immune traits; $\mu$ is the overall mean; $S_{i}$ is the effect of the season; $S x_{j}$ is effect of the sex; $B_{k}$ is the effect of the breed; $G_{l}$ is the effect of genotypes of the SNP; $\mathrm{p}_{k m}$ is the random effect of the sire within breed; $\mathrm{q}_{k m n}$ is the random effect of the dam within breed and sire; $e_{i j k l m n o p}$ is the random residual effect.

\section{RESULTS AND DISCUSSION}

\section{Tissue expression of porcine NRAMP1 gene}

To determine tissue distribution of the porcine NRAMPl gene, reverse transcription quantitative PCR (RT-PCR) was applied on nine different tissues of samples. Results showed that the mRNA of NRAMP1 was expressed in all analyzed tissues (Figure 1). The levels of NRAMP1 expressed in liver, spleen and lymphoid were higher, comparatively, while the levels in brain and kidney were lower. NRAMP1 gene expression has been observed by RT-PCR in different tissues from chickens where higher expression levels were found in liver, spleen, thymus and much lower expression levels in brain, kidney, which is consistent with our results in pigs (He et al., 2013).

\section{Polymorphisms detection of porcine NRAMP1 gene}

Sequence comparisons of the same PCR fragment among four pig populations detected one SNP 


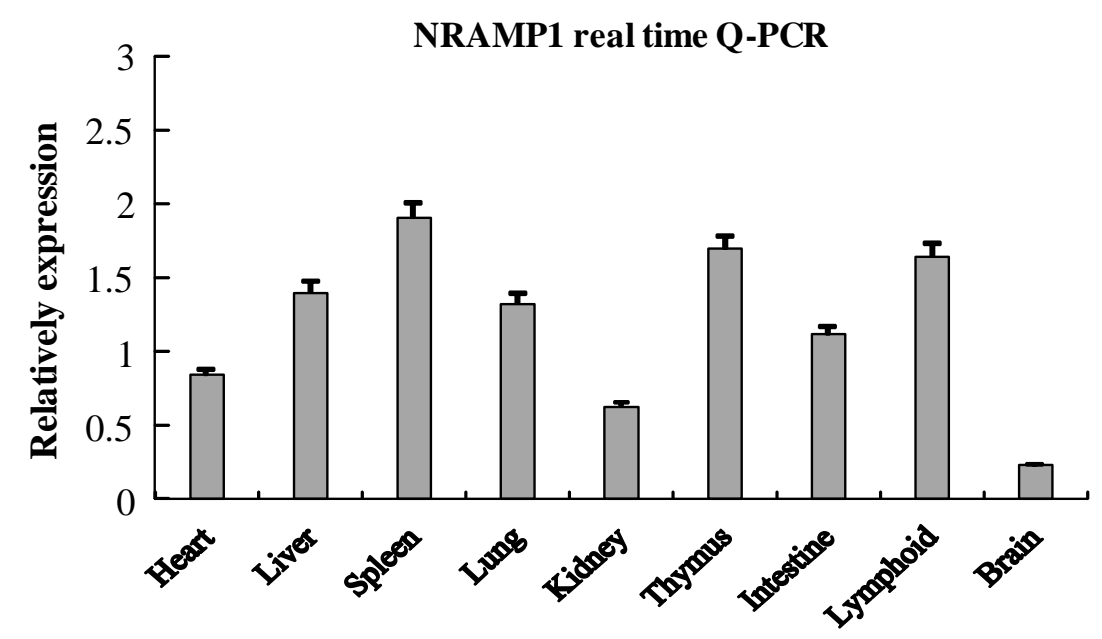

Figure 1. Expression of porcine NRAMP1 mRNA detected by real time Q-PCR in different porcine tissues. The relative expression level of NRAMP1 mRNA to GAPDH mRNA was evaluated using the $2^{-\triangle \Delta C T}$ method. NRAMP1, natural resistance-associated macrophage protein 1; Q-PCR, real-time quantitative polymerase chain reaction; GAPDH, glyceraldehyde3-phosphate dehydrogenase.

(ENSSSCG00000025058: g.130 C>T) in exon1 and one SNP (ENSSSCG00000025058: g.657 $\mathrm{A}>\mathrm{G}$ ) in intron1 region of the porcine NRAMP1 gene. The two SNPs were both synonymous mutations, did not induce substitution of an amino acid. The SNP (ENSSSCG00000025058:g.130 $\mathrm{C}>\mathrm{T}$ ) was genotyped by directly sequencing the PCR products and the other SNP (ENSSSCG00000025058: g.657 A>G) was genotyped by PCR-RFLP method in all 466 pigs (Figure 2). The genotypes and allele frequencies of the identified SNPs in four different pig populations are presented in Table 2. For the SNP (ENSSSCG00000025058:g.130 C>T), the allele $\mathrm{T}$ has higher frequencies than allele $\mathrm{C}$ in Wannan Black, Huai and Wei pig populations, but have lower allele frequencies in Large White population. In addition, for the SNP (ENSSSCG00000025058: g.657 A>G), the allele $\mathrm{G}$ was obviously with high allele frequencies, the allele A has lower frequencies and AA genotype is not detected in four pig populations.

\section{Association analysis of porcine NRAMP1 gene in four pig populations}

Base on the aforementioned work, we performed association analysis to confirm whether the identified SNPs from the four breeds have relationship with immune traits. Results showed that all the traits among four breeds were significantly different except ratio of $\mathrm{CD}^{-} \mathrm{CD} 8^{-} \mathrm{T}$ lymphocyte $(\mathrm{p}<0.05)$ (Table 3). The MO\% levels of Large White was significantly higher than those of Huai and Wei pig (Table 3); The $\mathrm{CD} 4^{+} \mathrm{CD}^{-}, \mathrm{CD}^{+} \mathrm{CD}^{+} \mathrm{T}$ lymphocyte levels of Large White was significantly higher than those of Wannan Black, Huai and Wei pig (Table 3); In contrast, Wannan Black, Huai and Wei pigs had a significantly higher WBC, $\mathrm{CD}^{-} \mathrm{CD}^{+} \mathrm{T}$ lymphocyte level than Large White $(p<0.05)$ (Table 3). As reported in a previous study, the results implied that genetic background is one of important

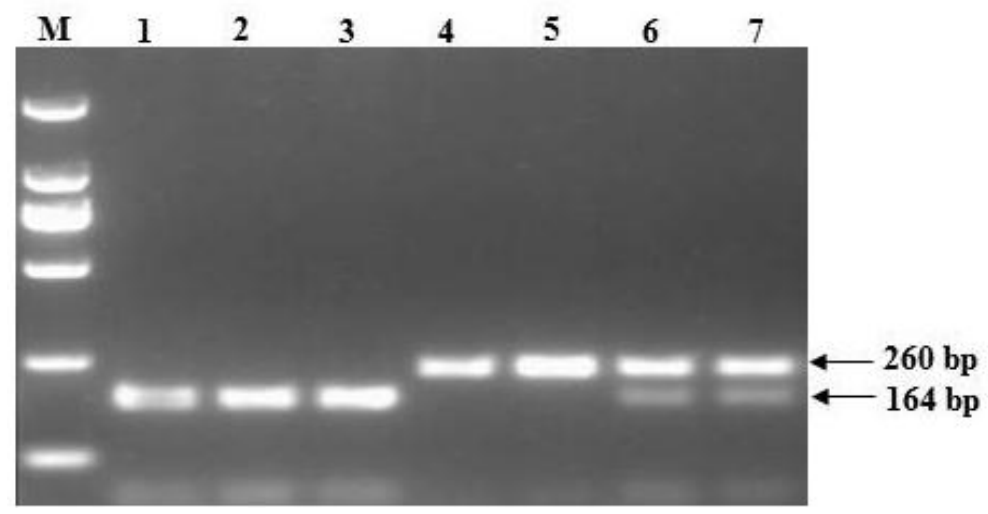

Figure 2. PCR-SmaI-RFLP analysis of the SNP (ENSSSCG00000025058:g. 657A>G) in porcine NRAMP1 gene. The lane M is Marker DL2000; The lane 1-3 are AA genotype, and 4-5 are GG genotype, and 6-7 are AG heterozygote. PCR-SmaI-RFLP, polymerase chain reaction-SmaI-Restriction Fragment Length Polymorphism; SNP, single nucleotide polymorphism; NRAMP1, natural resistanceassociated macrophage protein 1 . 
Table 2. Genotype and allele frequencies of the SNPs detected in the porcine NRAMP1 gene

\begin{tabular}{|c|c|c|c|c|c|c|c|c|c|c|}
\hline \multirow{3}{*}{ Breed } & \multicolumn{5}{|c|}{ (ENSSSCG00000025058:g.130 C>T) } & \multicolumn{5}{|c|}{ (ENSSSCG00000025058:g. $657 \mathrm{~A}>\mathrm{G}$ ) } \\
\hline & \multicolumn{3}{|c|}{ Genotype frequencies } & \multicolumn{2}{|c|}{ Allele frequencies } & \multicolumn{3}{|c|}{ Genotype frequencies } & \multicolumn{2}{|c|}{ Allele frequencies } \\
\hline & $\mathrm{CC}$ & $\mathrm{CT}$ & TT & $\mathrm{C}$ & $\mathrm{T}$ & AA & $\mathrm{AG}$ & GG & $\mathrm{A}$ & $\mathrm{G}$ \\
\hline Large White (140) & 0.54 & 0.18 & 0.28 & 0.63 & 0.37 & 0 & 0.32 & 0.68 & 0.16 & 0.84 \\
\hline Wannan Black (118) & 0.17 & 0.21 & 0.62 & 0.28 & 0.72 & 0 & 0.28 & 0.72 & 0.14 & 0.86 \\
\hline Huai (105) & 0.23 & 0.31 & 0.46 & 0.39 & 0.61 & 0 & 0.25 & 0.75 & 0.12 & 0.88 \\
\hline Wei (103) & 0.21 & 0.22 & 0.57 & 0.32 & 0.68 & 0 & 0.22 & 0.78 & 0.11 & 0.89 \\
\hline
\end{tabular}

SNP, single nucleotide polymorphism; NRAMP1, natural resistance-associated macrophage protein 1.

The number of animals in each breed is indicated between parentheses.

factors that influence the immune capacity (Liu et al., 2011).

The results of association analysis between SNPs and immune traits also showed that the SNP (ENSSSCG00000025058: g.130 C>T) of NRAMP1 gene was significantly associated with level of $\mathrm{WBC} \%, \mathrm{MO} \%$, $\mathrm{MC} \%$ and $\mathrm{CD}^{-} \mathrm{CD}^{+}{ }^{+} \mathrm{T}$ lymphocyte $(\mathrm{p}<0.05)$ (Table 4). The other SNP (ENSSSCG00000025058: g.657 A>G) was highly significantly associated with the level of $\mathrm{MO} \%$, $\mathrm{MC} \%$ and $\mathrm{CD}^{-} \mathrm{CD}^{+} \mathrm{T}$ lymphocyte ( $\left.\mathrm{p}<0.05\right)$ (Table 4). In further multiple tests for the SNP (ENSSSCG00000025058: g.130 C>T), the levels of $\mathrm{MO} \%$ and $\mathrm{MC} \%$ of pigs associated with genotype $\mathrm{CC}$ were significantly higher than with genotype TT $(\mathrm{p}<0.05)$, but the levels of $\mathrm{WBC} \%$ and $\mathrm{CD} 4^{-} \mathrm{CD} 8^{+} \mathrm{T}$ lymphocyte with genotype $\mathrm{CC}$ were significantly lower than those with genotype TT $(\mathrm{p}<0.05)$. For the other SNP (ENSSSCG00000025058: g.657 A>G), the levels of $\mathrm{MO} \%, \mathrm{MC} \%$, and $\mathrm{CD} 4^{-} \mathrm{CD} 8^{+} \mathrm{T}$ lymphocyte of pigs associated with genotype GG were significantly higher than those with genotype AA ( $\mathrm{p}<0.01)$.

The NRAMP1 gene was firstly isolated by positional cloning the host resistance locus $\mathrm{Bcg} / \mathrm{Ity} / \mathrm{Lsh}$, and mutations at this locus impair the resistance of mice to infections with intracellular parasites, such as Salmonella, Leishmania and Mycobacterium (Vidal et al., 1993). NRAMPl gene is expressed in monocyte/macrophages and has key roles in phagosome maturation and cell activation. Moreover,
NRAMP1 gene has an important role in activation of a large subset of innate lymphocytes that are critical sources of interferon $-\gamma$ (Hedges et al., 2013). In humans, mutations in NRAMP1 gene are associated with T1D (Yang et al., 2011), tuberculosis risk (Meilang et al., 2012) and pulmonary Mycobacterium avium complex infection (Sapkota et al., 2012). In pigs, a single nucleotide polymorphism in the sixth intron of the NRAMPI gene has been found to be significantly associated with polymorphonuclear leukocyte levels, cytotoxin on monocytes and 180-day-old body weight (Wu et al., 2008). In our study, the SNPs of NRAMP1 gene were significantly associated with monocytes traits and $\mathrm{CD}^{-} \mathrm{CD} 8^{+} \mathrm{T}$ lymphocyte. Monocytes play critical roles in immunopathology. NRAMP1 mediates the iron homeostasis in monocytes/macrophages and hence modulates their response to acute inflammatory stimuli (Wyllie et al., 2002). So the higher percentage of monocytes in animals with CC genotype in our study may imply that the CC genotype enhances the activity of the monocytes by mediating iron homeostasis. On the other hand, the $\mathrm{CD}^{-}{ }^{-} \mathrm{CD} 8^{+} \mathrm{T}$ lymphocytes are also important traits in disease resistance and could mediate the activity of the CSFV-specific cytotoxic T lymphocyte (Pauly et al., 1995). The differentiation of the $\mathrm{T}$ lymphocyte into CD4/CD8 subpopulations is induced by the antigen-presenting cells (APCs) such as macrophages, which in turn are regulated

Table 3. Association analysis of immune traits in four pig breeds

\begin{tabular}{lccccc}
\hline \multirow{2}{*}{ Traits } & \multicolumn{4}{c}{ Breeds (Least square mean \pm SE $)$} \\
\cline { 2 - 6 } & $\begin{array}{c}\text { Large White } \\
(\mathrm{n}=140)\end{array}$ & $\begin{array}{c}\text { Wannan Black } \\
(\mathrm{n}=118)\end{array}$ & $\begin{array}{c}\text { Huai } \\
(\mathrm{n}=105)\end{array}$ & $\begin{array}{c}\text { Wei } \\
(103)\end{array}$ & $\mathrm{p}$ value \\
\hline WBC $(\mathrm{g} / \mathrm{L})$ & $18.81 \pm 0.81^{\mathrm{a}}$ & $19.92 \pm 0.93^{\mathrm{b}}$ & $20.25 \pm 1.02^{\mathrm{b}}$ & $21.35 \pm 1.16^{\mathrm{b}}$ & $0.043^{*}$ \\
$\mathrm{LY} \%(\%)$ & $59.22 \pm 1.28^{\mathrm{a}}$ & $60.60 \pm 1.70^{\mathrm{a}}$ & $61.84 \pm 1.82^{\mathrm{a}}$ & $63.84 \pm 1.86^{\mathrm{b}}$ & $0.048^{*}$ \\
$\mathrm{MO} \%(\%)$ & $15.31 \pm 0.43^{\mathrm{A}}$ & $14.97 \pm 0.72^{\mathrm{A}}$ & $13.18 \pm 0.36^{\mathrm{B}}$ & $14.18 \pm 0.42^{\mathrm{B}}$ & $0.024^{*}$ \\
$\mathrm{MC}(\%)$ & $83.21 \pm 5.21^{\mathrm{A}}$ & $83.32 \pm 6.54^{\mathrm{A}}$ & $85.41 \pm 7.63^{\mathrm{A}}$ & $81.29 \pm 5.82^{\mathrm{B}}$ & $0.013^{*}$ \\
$\mathrm{CD} 4^{-} \mathrm{CD} 8^{-}(\%)$ & $11.41 \pm 0.21^{\mathrm{B}}$ & $10.84 \pm 0.24^{\mathrm{B}}$ & $10.33 \pm 0.23$ & $10.27 \pm 0.18$ & 0.574 \\
$\mathrm{CD} 4^{+} \mathrm{CD} 8^{-}(\%)$ & $19.70 \pm 0.73^{\mathrm{A}}$ & $13.62 \pm 0.59^{\mathrm{B}}$ & $11.46 \pm 0.57^{\mathrm{B}}$ & $13.38 \pm 0.64^{\mathrm{B}}$ & $0.019^{*}$ \\
$\mathrm{CD} 4^{-} \mathrm{CD} 8^{+}(\%)$ & $39.64 \pm 0.72^{\mathrm{A}}$ & $44.38 \pm 0.93^{\mathrm{B}}$ & $51.17 \pm 1.05^{\mathrm{B}}$ & $48.25 \pm 1.06^{\mathrm{B}}$ & $0.026^{*}$ \\
$\mathrm{CD}^{+} \mathrm{CD} 8^{+}(\%)$ & $35.41 \pm 0.67^{\mathrm{A}}$ & $30.43 \pm 0.55^{\mathrm{B}}$ & $29.65 \pm 0.64^{\mathrm{B}}$ & $28.42 \pm 0.63^{\mathrm{B}}$ & $0.032^{*}$ \\
\hline
\end{tabular}

SE, standard error; WBC, white blood cell count; LY\%, lymphocyte count percentage; MO\%, monocytes count percentage; MC (\%), rate of cytotoxin in monocyte; $\mathrm{CD}^{+/} \mathrm{CD}^{+/}$T lymphocyte subsets.

${ }^{a, b}$ Signed by small letters differ significantly at $\mathrm{p}<0.05$.

${ }^{\mathrm{A}, \mathrm{B}}$ Means signed by capital letters differ significantly at $\mathrm{p}<0.01$. 
Table 4. Association analysis and multiple tests of the SNPs of NRAMP1 gene in four pig populations

\begin{tabular}{|c|c|c|c|c|c|}
\hline \multirow{3}{*}{ Immune traits } & \multirow{2}{*}{\multicolumn{2}{|c|}{$\frac{\text { p-value }}{(\text { ENSSSCG00000025058 ) }}$}} & \multirow{3}{*}{\multicolumn{3}{|c|}{$\begin{array}{c}\text { Polymorphism genotypes } \\
\text { (Least square mean } \pm \mathrm{SE} \text { ) }\end{array}$}} \\
\hline & & & & & \\
\hline & g. $130 \mathrm{C}>\mathrm{T}$ & g. $657 \mathrm{~A}>\mathrm{G}$ & & & \\
\hline \multirow[t]{3}{*}{ WBC (g/L) } & $0.031^{*}$ & 0.724 & & g.130 C>T & \\
\hline & & & $\mathrm{CC}$ & CT & TT \\
\hline & & & $18.73 \pm 0.84^{\mathrm{a}}$ & $19.94 \pm 0.91^{b}$ & $20.46 \pm 0.96^{b}$ \\
\hline LY \% (\%) & 0.472 & 0.641 & & & \\
\hline \multirow[t]{6}{*}{ MO \% (\%) } & $0.024 *$ & $0.012 *$ & & g. $130 \mathrm{C}>\mathrm{T}$ & \\
\hline & & & $\mathrm{CC}$ & CT & TT \\
\hline & & & $15.12 \pm 0.41^{\mathrm{a}}$ & $14.74 \pm 0.39^{\mathrm{a}}$ & $14.28 \pm 0.32^{b}$ \\
\hline & & & & g. $657 \mathrm{~A}>\mathrm{G}$ & \\
\hline & & & AA & $\mathrm{AG}$ & GG \\
\hline & & & $13.64 \pm 0.34^{\mathrm{A}}$ & $14.72 \pm 0.39^{\mathrm{B}}$ & $15.33 \pm 0.42^{\mathrm{B}}$ \\
\hline \multirow[t]{6}{*}{$\mathrm{MC}(\%)$} & $0.013^{*}$ & $0.019^{*}$ & & g.130 C>T & \\
\hline & & & $\mathrm{CC}$ & $\mathrm{CT}$ & $\mathrm{TT}$ \\
\hline & & & $84.89 \pm 6.45^{\mathrm{A}}$ & $84.31 \pm 6.26^{\mathrm{A}}$ & $81.43 \pm 6.11^{\text {B }}$ \\
\hline & & & & g.657 A > G & \\
\hline & & & AA & $\mathrm{AG}$ & GG \\
\hline & & & $80.81 \pm 6.03^{\mathrm{A}}$ & $83.24 \pm 6.27^{\text {B }}$ & $84.92 \pm 6.42^{\text {B }}$ \\
\hline $\mathrm{CD}^{-} \mathrm{CD}^{-}(\%)$ & 0.051 & 0.062 & & & \\
\hline $\mathrm{CD}^{+} \mathrm{CD}^{-}(\%)$ & 0.871 & 0.693 & & & \\
\hline \multirow[t]{6}{*}{$\mathrm{CD} 4^{-} \mathrm{CD}^{+}(\%)$} & $0.023^{*}$ & $0.037 *$ & & g. $130 \mathrm{C}>\mathrm{T}$ & \\
\hline & & & $\mathrm{CC}$ & $\mathrm{CT}$ & TT \\
\hline & & & $40.46 \pm 0.81^{\mathrm{A}}$ & $42.17 \pm 0.91^{\mathrm{A}}$ & $50.23 \pm 1.03^{\mathrm{B}}$ \\
\hline & & & & g. $657 \mathrm{~A}>\mathrm{G}$ & \\
\hline & & & AA & $\mathrm{AG}$ & GG \\
\hline & & & $41.07 \pm 0.84^{\mathrm{A}}$ & $48.34 \pm 0.93^{\text {В }}$ & $51.13 \pm 1.08^{\mathrm{B}}$ \\
\hline $\mathrm{CD}^{+} \mathrm{CD}^{+}(\%)$ & 0.962 & 0.874 & & & \\
\hline
\end{tabular}

SNP, single nucleotide polymorphism; NRAMP1, natural resistance-associated macrophage protein 1; SE, standard error; WBC, white blood cell count; $\mathrm{LY} \%$, lymphocyte count percentage; $\mathrm{MO} \%$, monocytes count percentage; $\mathrm{MC}(\%)$, rate of cytotoxin in monocyte; $\mathrm{CD}^{+/}{ }^{+-} \mathrm{CD}^{++_{-}^{-}}$T lymphocyte subsets. $\mathrm{p}<0.05 ;{ }^{\mathrm{a}, \mathrm{b}}$ Statistically different of least square means $(\mathrm{p}<0.05) .{ }^{\mathrm{A}, \mathrm{B}}$ Statistically different of least square means $(\mathrm{p}<0.01)$.

by the NRAMP1 gene (Smit et al., 2004). Therefore, the higher $\mathrm{CD}^{-} \mathrm{CD}^{+}$percentage in animals with $\mathrm{GG}$ genotype in our study indicate that GG genotype may enhance the differentiation of the $\mathrm{T}$ lymphocyte into $\mathrm{CD} 4^{-} \mathrm{CD} 8^{+}$by regulating the activity of APCs.

As the immune system plays an essential role in disease resistance of animals, genes involved in the response of immune system could be regarded as the candidate genes for selection (Crawley et al., 2005). The two SNPs were not missense mutations or induced amino acid substitutions. However, the synonymous SNPs can also affect protein expression by alteration or increasing the stability of mRNA (Capon et al., 2004). Additionally, a "silent" polymorphism can change substrate specificity (Kimchi-Sarfaty et al., 2007). Our results provided a straightforward insight that NRAMP1 gene which has effects on levels of $\mathrm{WBC} \%$, $\mathrm{MO} \%, \mathrm{MC} \%, \mathrm{CD}^{-} \mathrm{CD}^{+}{ }^{-} \mathrm{T}$ lymphocytes and it could serve as a genetic marker for immune traits. But the number of pigs analyzed in our study was restricted, further investigations are needed to confirm the relationships between the SNPs with immune traits among other pig populations.

In summary, the mRNA expression results revealed that the porcine NRAMPl gene was expressed widely in liver, spleen, lymphoid, kidney, thymus, lung, brain and heart. One SNP (ENSSSCG00000025058: g.130 C>T) in exon1 and one SNP (ENSSSCG00000025058: g.657 A>G) in intron1 region of porcine NRAMP1 gene were found. The further association analysis showed that the two SNPs were significantly associated with level of $\mathrm{WBC} \%, \mathrm{MO} \%, \mathrm{MC} \%$ and $\mathrm{CD}^{-} \mathrm{CD}^{+} \mathrm{T}$ lymphocytes respectively. The results indicated that NRAMPl gene could be regarded as a genetic marker for these immune traits in porcine disease resistance breeding.

\section{ACKNOWLEDGMENTS}

This work was supported by the National Natural Science Foundation of China (31171200), the Anhui Provincial Natural Science Foundation (1408085QC55), the National High Science and Technology Foundation of China "863" (2011AA100302), the Project of Anhui 
Province Scientific Technology Plan (1301031032), and the Agricultural Science and Technology Achievement Transformation Foundation of China (2012GB2C300207).

\section{REFERENCES}

Ates, O., L. Dalyan, B. Musellim, G. Hatemi, H. Türker, G. Ongen, V. Hamuryudan, and A. Topal-Sarikaya. 2009. NRAMP1 (SLC11A1) gene polymorphisms that correlate with autoimmune versus infectious disease susceptibility in tuberculosis and rheumatoid arthritis. Int. J. Immunogenet. 36: 15-19.

Blackwell, J. M., S. Searle, T. Goswami, and E. N. Miller. 2000. Understanding the multiple functions of Nramp1. Microbes Infect. 2:317-321.

Blackwell, J. M., S. Searle, H. Mohamed, and J. K. White. 2003. Divalent cation transport and susceptibility to infectious and autoimmune disease: Continuation of the Ity/Lsh/Bcg/Nramp I/ Slc11a1 gene story. Immunol. Lett. 85:197-203.

Canonne-Hergaux, F., S. Gruenheid, P. Ponka, and P. Gros. 1999. Cellular and subcellular localization of the Nramp2 iron transporter in the intestinal brush border and regulation by dietary iron. Blood 93:4406-4417.

Capon, F., M. H. Allen, M. Ameen, A. D. Burden, D. Tillman, J. N. Barkerand, and R. C. Trembath. 2004. A synonymous SNP of the corneodesmosin gene leads to increased mRNA stability and demonstrates association with psoriasis across diverse ethnic groups. Hum. Mol. Genet. 13:2361-2368.

Courville, P., R. Chaloupka, and M. F. Cellier. 2006. Recent progress in structure-function analyses of Nramp protondependent metal-ion transporters. Biochem. Cell Biol. 84:960978 .

Crawley, A. M., B. Mallard, and B. N. Wilkie. 2005. Genetic selection for high and low immune response in pigs: Effects on immunoglobulin isotype expression. Vet. Immunol. Immunopathol. 108:71-76.

Gazouli, M., V. Atsaves, G. Mantzaris, M. Economou, G. Nasioulas, K. Evangelou, A. J. Archimandritis, and N. P. Anagnou. 2008. Role of functional polymorphisms of NRAMP1 gene for the development of Crohn's disease. Inflamm. Bowel. Dis. 14:1323-1330.

Hellemans, J., G. Mortier, A. De Paepe, F. Speleman, and J. Vandesompele. 2007. qBase relative quantification framework and software for management and automated analysis of realtime quantitative PCR data. Genome Biol. 8:R19.

He, X. M., M. X. Fang, Z. T. Zhang, Y. S. Hu, X. Z. Jia, D. L. He, S. D. Liang, Q. H. Nie, and X. Q. Zhang. 2013. Characterization of chicken natural resistance-associated macrophage protein encoding genes (Nramp1 and Nramp2) and association with salmonellosis resistance. Genet. Mol. Res. 12:618-630.

Hedges, J. F., E. Kimmel, D. T. Snyder, M. Jerome, and M. A. Jutila. 2013. Solute carrier $11 \mathrm{~A} 1$ is expressed by innate lymphocytes and augments their activation. J. Immunol. 190:4263-4273.
Kimchi-Sarfaty, C., J. M. Oh, I. W. Kim, Z. E. Sauna, A. M. Calcagno, S. V. Ambudkar, and M. M. Gottesman. 2007. A "silent" polymorphism in the MDRl gene changes substrate specificity. Science 315(5811):525-528

Liu, Y., X. T. Qiu, J. J. Xu, F. Hu, Y. H. Li, H. J. Li, Y. F. Gong, and Q. Zhang. 2011. Association analysis between the polymorphism of the SLC11A1 gene and immune response traits in pigs. Asian J. Anim. Vet. Adv. 6:580-586.

Meilang, Q., Y. Zhang, J. Zhang, Y. Zhao, C. Tian, J. Huang, and H. Fan. 2012. Polymorphisms in the SLC11Al gene and tuberculosis risk: a meta-analysis update. Int. J. Tuberc. Lung Dis. 16:437-446.

Pauly, T., K. Elbers, M. Konig, T. Lengsfeld, A. Saalmuller, and H. J. Thiel. 1995. Classical swine fever virus-specific cytotoxic T lymphocytes and identification of a $\mathrm{T}$ cell epitope. J. Gen. Virol. 76:3039-3049.

Sambrook, J., E. F. Fritsch, and T. Maniatis. 1989. Molecular Cloning: A Laboratory Manual, 2nd edn. Cold Spring Harbor Laboratory Press, New York, USA.

Sapkota, B. R., M. Hijikata, I. Matsushita, G. Tanaka, R. Ieki, N. Kobayashi, E. Toyota, H. Nagai, A. Kurashima, K. Tokunaga, and N. Keicho. 2012. Association of SLC11A1 (NRAMP1) polymorphisms with pulmonary Mycobacterium avium complex infection. Hum. Immunol. 73:529-536.

Smit, J. J., G. Folkerts, and F. P. Nijkamp. 2004. Ramp-ing up allergies: Nrampl (Slc1la1), macrophages and the hygiene hypothesis. Trends Immunol. 25:342-347.

Tanaka, G., J. Shojima, I. Matsushita, H. Nagai, A. Kurashima, K. Nakata, E. Toyota, N. Kobayashi, K. Kudo, and N. Keicho. 2007. Pulmonary Mycobacterium avium complex infection: Association with NRAMP1 polymorphisms. Eur. Respir. J. 30: 90-96.

Tuggle, C. K., C. B. Schmitz, and D. Gingerich-Feil. 1997. Rapid communication: cloning of a pig full-length NRAMP1 cDNA. J. Anim. Sci. 75:277.

Tuggle, C. K., L. Marklund, T. J. Stabel, M. A. Mellencamp, and A. Stumbaugh. 2005. Genetic markers for screening animals for improved disease resistance (NRAMP). United States Patent, Patent No. :US 6,844,159 B2.

Vidal, S. M., D. Malo, K. Vogan, E. Skamene, and P. Gros. 1993. Natural resistance to infection with intracellular parasites: isolation of a candidate for Bcg. Cell 73:469-485.

Wu, H., D. Cheng, and L. Wang. 2008. Association of polymorphisms of Nrampl gene with immune function and production performance of Large White pig. J. Genet. Genomics 35:91-95.

Wyllie, S., P. Seu, and J. A. Goss. 2002. The natural resistanceassociated macrophage protein 1 NRAMP1 (formerly Nramp1) and iron metabolism in macrophages. Microbes Infect. 4:351359

Yang, J. H., K. Downes, J. M. Howson, S. Nutland, H. E. Stevens, N. M. Walker, and J. A. Todd. 2011. Evidence of association with type 1 diabetes in the SLC11A1 gene region. BMC Med. Genet. 12:59. 